\title{
Gender is not a relevant matter in habitat selection of the longsnout seahorse Hippocampus reidi Ginsburg, 1933 (Teleostei: Syngnathidae)
}

\begin{abstract}
Habitat selection in certain species may vary according to context and environmental conditions. Sexual differences regarding habitat use have been reported for several species, such as mammals, birds and fish, and have been explained by protection and food resource contexts. This issue is not well studied in seahorses, but it may provide useful data for the management of threatened species. The Longsnout Seahorse has recently been considered near threatened, but many gaps regarding its habitat use are still noted. Seahorses display a particular breeding characteristic, in which males carry the embryos inside a breeding pouch, therefore leading to supposed careful selection of breeding habitats, avoiding predation risks and choosing habitats with high prey availability. In this context, this study aimed to verify differences in habitat selection between male and female Longsnout Seahorse Hippocampus reidi specimens along the coast of the state of Rio de Janeiro. This study took place at 11 sites along the Rio de Janeiro coastline, in southeastern Brazil. Random belt transects $(20 \times 5 \mathrm{~m})$ were assessed, searching for seahorses and their holdfasts. Random quadrats $(50 \times 50 \mathrm{~cm})$ divided into 100 cells $/$ each were placed along the transects and benthic cover was counted, in order to establish substrate availability. Results suggested that males select fewer substrate types than females, but no statistical difference was detected. Both male and female $H$. reidi specimens select mostly Sargassum vulgare as a frequent habitat. The strong association of $H$. reidi to these seaweed beds suggests vulnerability concerning the degradation of this habitat.
\end{abstract}

Keywords: brazil, coastal water, rocky reef, fish
Volume 10 Issue 5 - 2021

\author{
Natalie $V$ Freret-Meurer, ${ }^{1,3}$ Oliver AFC \\ Pereira, ${ }^{2}$ Tatiane C Fernández,' Bruno $C$ \\ Meurer $^{2}$ \\ 'Laboratório de Comportamento Animal e Conservação0, \\ Universidade Santa Úrsula, Rua Fernando Ferrari, Brazil \\ 2Laboratório de Ecologia Marinha, Universidade Santa Úrsula. \\ Rua Fernando Ferrari, Brazil \\ ${ }^{3}$ Departamento de Ecologia, Instituto de Biologia Roberto \\ Alcantara Gomes, Universidade do Estado do Rio de Janeiro. \\ Avenida São Francisco Xavier, Brazil
}

Correspondence: Natalie V Freret-Meurer, Universidade Santa Úrsula. Rua Fernando Ferrai, 75 - Botafogo, Brazil,

Tel +55 2l 98|4|4|29, Email nataliefreret@yahoo.com.br

Received: September 28, 2021 | Published: October 13, 2021

\section{Introduction}

Reef benthic community arrangement is variable and depends on several ecological processes, such as predation, disturbance and competition, forming a mosaic habitat. Microhabitats comprising different sessile species may be used by several reef fishes for shelter, reproduction and feeding sites. ${ }^{1}$ Habitat selection depends on the costs and benefits provided by the site and on the biological needs of the species. During reproduction, some reef fish consider parental care investment for habitat selection. ${ }^{2}$

Seahorses are benthic fishes that have a patchy distribution along the reef. ${ }^{3}$ The factors that drive the patchy distribution of seahorses in reefs are still unknown, but substrate plays an important role in their ecology, as their perpendicular body and a prehensile tail instead of a caudal fin create a dependent relationship between seahorses and substrates. The selection of specific substrates by these animals can be explained by several factors, such as holdfast availability, predator or prey abundance/occurrence 4 and mate availability. However, ecological differences in parental care between males and females may also influence habitat selection, as males become more sedentary during pregnancy ${ }^{5}$ compared to females, and should, therefore, carefully choose their habitat, while females can be more generalist.

The Brazilian seahorse Hippocampus reidi Ginsburg, 1933 is distributed throughout the Brazilian coast. ${ }^{6,7}$ It is considered near threatened by the Red List of Threatened Species of the World, ${ }^{8}$ but figures in the National Red List as vulnerable (MMA 2018). A population decline has been documented, ${ }^{9}$ in large part due to bycatch, international trade and habitat loss.

In this context, the present study aims to verify which microhabitats are predominantly used by male and female Hippocampus reidi seahorses throughout the coast of Rio de Janeiro, assessing possible differences in habitat selection and providing information on seahorse habitat conservation along the Rio de Janeiro state coast.

\section{Material and methods}

This study took place in 11 sites along the Rio de Janeiro state coastline (Figure 1).

Three random belt transects $(20 \times 5 \mathrm{~m})$ per site and per year were assessed from July 2006 to February 2009, in alternate months. Two observers swam (snorkeling) side by side along each transect. Since rocky reefs had up to $2,50 \mathrm{~m}$ and most of the animals occur at $1,50 \mathrm{~m}$ deep, ${ }^{9-11}$ snorkelling was the most adequate diving method. The divers recorded the following data: seahorse species, according to Lourie et al. ${ }^{12}$ sex, by the presence (male) or absence of the brood pouch (female) (Lourie 2003); height according to Lourie, ${ }^{12}$ to characterize specimens as adults $(>56 \mathrm{~mm})$ or juveniles $(<56 \mathrm{~mm})^{11}$ and, finally, type of holdfast. ${ }^{13}$ 


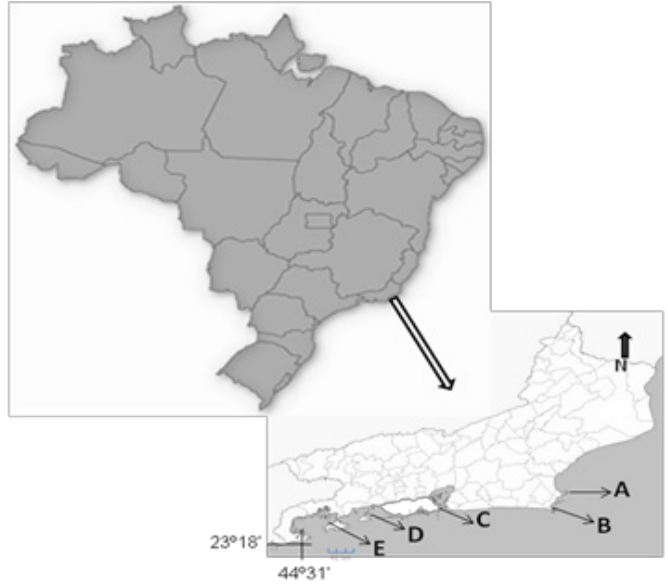

Figure I Study sites: (A) Armação de Búzios (Praia de João Fernandes). (B) Arraial do Cabo (Praia do Forno), (C) Rio de Janeiro city (Praia da Urca), (D) Mangaratiba (Praia Grande), (E) Angra dos Reis (Praia do Café, Pontal, Aventureiro - Ilha Grande, Lagoa Verde - Ilha Grande, Praia da Longa - Ilha Grande, Provetá - Ilha Grande, Praia de Araçatiba - Ilha Grande).

Substrate availability was determined by the benthic cover in each transect. One random quadrat $(50 \times 50 \mathrm{~cm})$ divided into $100 \mathrm{cells} /$ each was released per transect at each site, in order to quantify the benthic community. Biota was identified to the lowest taxonomic level possible in the field. If in doubt, a small sample was taken to the laboratory for further identification.

\section{Data analysis}

The Frequency of Occurrence Index (FO) (Dajoz 1983) was applied to characterize holdfast use for the observed seahorses. Holdfasts with $\mathrm{FO} \geq 50 \%$ : constantly used by seahorses; FO between $49 \% \leq 25 \%$ : occasionally used; and $\mathrm{FO}<25 \%$ : sporadically used. ${ }^{9}$ Total Frequency of Occurrence was calculated using all data per sex, while for Frequency of Occurrence/area, data per site and per sex were used.

We used the Ivlev Electivity Index (E) to identify the habitat preference according to habitat availability (Krebs, 1999). We calculated the Index as follow: $\mathrm{E}=(\mathrm{ri}-\mathrm{ni}) /(\mathrm{ri}+\mathrm{ni})$, where $\mathrm{E}$ is the measure of electivity, ri the relative abundance of habitat $i$ used by the seahorse as holdfast (as a percentage of the total holdfasts used by the seahorses) and $\mathrm{n}$ is the relative abundance of the same habitat in the environment. Electivity Index values approaching 1 indicate a preference for a certain micro-habitat, and values less than 1 , less preference. Difference in holdfast use between sexes was analysed by $t$ test for independent data, while relation between holdfast use and its availability was determined by Spearman Correlation.

\section{Results}

The studied rocky reefs were mostly composed by the soft coral Palythoa caribaeorum (36.48\%) and calcareous algae (24.14\%). Sandy bottom and rocks without any cover were also frequently registered (16.37\% and $12.38 \%$, respectively). The seaweed Sargassum vulgare and Dictyota sp. were recorded at $8 \%$ each (Table 1).

Table I Substrate availability according to percent cover (\%) along Rio de Janeiro State

\begin{tabular}{|c|c|c|c|c|}
\hline Substrate & & Mean \% & SD & Availability \% \\
\hline \multirow{6}{*}{ 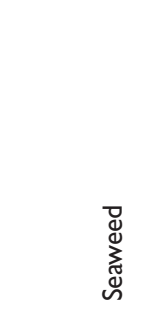 } & Calcareous & 24.14 & 31.31 & 18.87 \\
\hline & Filamentous algae & 1.45 & 8.46 & 0.94 \\
\hline & Caulerpa racemosa & 2.66 & 8.74 & 1.75 \\
\hline & Codium sp. & 0.08 & 0.50 & 0.05 \\
\hline & Dictyota sp. & 8.27 & 17.67 & 5.85 \\
\hline & Laurencia sp. & 2.27 & 10.62 & 1.52 \\
\hline \multirow{7}{*}{$\frac{\frac{\pi}{0}}{\frac{\pi}{2}}$} & Padina sp. & 0.72 & 2.26 & 0.50 \\
\hline & Rodophyta & 0.38 & 3.21 & 0.24 \\
\hline & Sargassum vulgare & 8.57 & 17.55 & 6.54 \\
\hline & Ulva sp. & $0.7 \mathrm{I}$ & 4.32 & 0.45 \\
\hline & Aplysina fulva & 0.98 & 3.59 & 0.65 \\
\hline & Monanchoraarburscula & 0.06 & 0.44 & 0.06 \\
\hline & Not idenfied & 0.14 & $\mathrm{I} .40$ & 0.09 \\
\hline \multirow{4}{*}{ 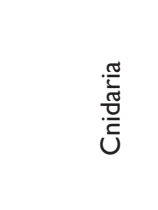 } & Palythoa sp. & 36.48 & 38.84 & 29.19 \\
\hline & Mussismiliahispida & 0.72 & 2.33 & 0.47 \\
\hline & Zoanthus sp. & 5.90 & 18.04 & 4.07 \\
\hline & Budonossoma sp. & 0.18 & 0.83 & 0.11 \\
\hline \multirow{4}{*}{ 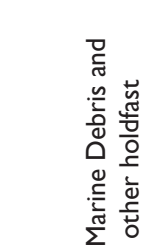 } & Piece of wood & 2.39 & 13.85 & 1.56 \\
\hline & Nylon rope & 0.07 & 0.70 & 0.04 \\
\hline & Sandy bottom & 16.37 & 28.97 & 11.39 \\
\hline & Rock & 12.38 & 20.89 & 9.69 \\
\hline
\end{tabular}


Table Continued...

\begin{tabular}{lllll}
\hline Substrate & & Mean \% & SD & Availability \% \\
\hline \multirow{2}{*}{ Mollusca } & Perna-perna & 7.17 & 23.70 & 4.53 \\
& Gastropoda & 0.01 & 0.10 & 0.01 \\
Tunicata & Phalusia nigra & 0.39 & 1.32 & 0.27 \\
\multirow{2}{*}{ Echinodermata } & Echinoidea & 0.77 & 2.01 & 0.51 \\
& Asteroidea & 0.06 & 0.34 & 0.04 \\
Crustacea & Cirripedia & 1.10 & 7.91 & 0.73 \\
\hline
\end{tabular}

A total of 123 seahorses were recorded in 132 transects, being 56 males and 67 females. All males were pregnant. Animals used a total of 15 different holdfasts (Table 1), but males were recorded grasping eight types of holdfasts, while females used thirteen. Although the total number of holdfasts seemed different among sex, no significant differences in the number of holdfasts among samples has been noticed $(\mathrm{p}=0.999 ; \mathrm{t}=0.000)$.

Seahorses constantly used Sargassumvulgare C. Agardh, at FO of $69.61 \%$ and $66.67 \%$ for males and females, respectively. The other substrates were barely used, with FO of less than $13 \%$ (Table 2) and, thus, considered sporadic. No significant FO differences between males and females were observed $(p=0.305 ; \mathrm{t}=1.052)$. There was also no significant relationship between benthic cover percentage and holdfast use frequency for either males $(\mathrm{p}=0.063 ; \mathrm{r}=0.31)$ or females $(p=0.06 ; r=0.32)$. However, when both sexes were taken together, a relationship between seahorse substrate holding FO and substrate availability was noted $(\mathrm{p}<0.001 ; \mathrm{r}=0.86)$, indicating a holdfast selection pattern.

Table 2 Frequency of occurrence (\%) (FO) of male and female holding each substrate

\begin{tabular}{|c|c|c|c|}
\hline & & FO(\%) Male & FO(\%) Female \\
\hline \multirow{7}{*}{ 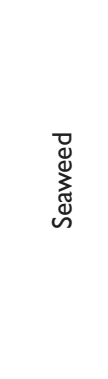 } & Calcareous & 5.36 & 1.67 \\
\hline & Caulerpa racemosa & 1.79 & 1.67 \\
\hline & Codium sp. & - & 1.67 \\
\hline & Dictyota sp. & 12.50 & 8.33 \\
\hline & Laurencia sp. & 0.02 & - \\
\hline & Padina sp. & - & 3.32 \\
\hline & Sargassum vulgare & 69.61 & 66.67 \\
\hline Porifera & Aplysina fulva & 5.36 & 5.00 \\
\hline Bryozoa & Bryozoa & - & 1.67 \\
\hline Cnidaria & Mussismiliahispida & - & 1.67 \\
\hline ס & Sand & - & 3.32 \\
\hline $\begin{array}{l}\frac{c}{\pi} \\
\stackrel{n}{=}\end{array}$ & Latex tube & - & 1.67 \\
\hline อั & Nylon rope & - & 1.67 \\
\hline 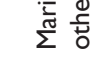 & Branch & 3.57 & - \\
\hline
\end{tabular}

Males preferred seaweed, such as Sargassumvulgare (0.58) and Dictyota sp. (0.18), as well as the sponge Aplysina fulva (0.09), but were occasionally observed holding calcareous algae and rock (-0.56 and -0.08 , respectively). Females preferred marine debris substrates, such as latex tubes and nylon ropes (0.95 and 0.77 , respectively), followed by natural benthic organisms, such as Sargassumvulgare (0.81), Aplysina fulva (0.75) and Codium sp. (0.53). The use of rocks, calcareous algae and sandy bottom was classified as occasional (-0.71, -0.70 and -0.55 , respectively) (Table 3 ).

Table 3 Ivlev Index for male and female considering all holdfasts used by both sexes

\begin{tabular}{|c|c|c|c|}
\hline & \multirow{2}{*}{ Substrate } & \multicolumn{2}{|c|}{ Ivlev Index } \\
\hline & & Male & Female \\
\hline \multirow{7}{*}{ 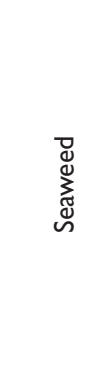 } & Padina sp & - & 0.74 \\
\hline & Sargassumvulgare & 0.58 & 0.81 \\
\hline & Laurenciasp & - & - \\
\hline & Dictyotaspp & 0.18 & 0.17 \\
\hline & Codiumsp & - & 0.53 \\
\hline & Caulerpa racemosa & 0.04 & -0.03 \\
\hline & Calcareous & -0.56 & -0.70 \\
\hline \multirow{5}{*}{ 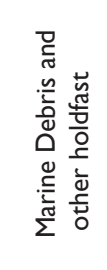 } & Sandy bottom & - & -0.55 \\
\hline & Latex tube & - & 0.95 \\
\hline & Nylon rope & - & 0.77 \\
\hline & Piece of wood & 0.05 & - \\
\hline & Rock & -0.08 & -0.71 \\
\hline \multirow{2}{*}{ Porifera } & Aplysina fulva & 0.09 & 0.75 \\
\hline & Monanchoraarbuscula & 0.01 & - \\
\hline Cnidaria & Mussismiliahispida & - & 0.56 \\
\hline
\end{tabular}

\section{Discussion}

Seahorses were observed grasping several substrates, but data suggest that they do not choose substrates randomly. Both sexes were frequently found in Sargassum vulgare beds displaying a certain preference, even as this is not the most available substrate. The absence of sexual difference in habitat selection may be related to three main issues: prey availability, protection and the seahorse mating system.

Prey availability may influence decisions, considering that the habitat reported here in presents potentially high quality. The association between seahorses and Sargassum vulgare beds has been reported previously ${ }^{10-12,15}$ and seems to be related to feeding opportunities and protection. The rich fauna associated to Sargassum vulgare beds serves as seahorse prey ${ }^{15}$ and seahorse ability to change colour and develop skin filaments allows them to look similar to seaweed, improving preying efficiency by applying camouflage. Another issue is that this species has been reported to be very 
sedentary and according to Manning et al. 2019, seahorses tend to be more sedentary in complex habitat with a large amount of prey.

The sponge A. fulva was also important to $H$. reidi in the present study, as reported by Freret-Meurer et al. ${ }^{11}$ also in Rio de Janeiro. Sponge channels provide shelter for many invertebrates (Bezerra and Coelho 2006) ${ }^{17}$ such as several crustaceans and worms, that also belong toH. reidi's diet. ${ }^{18}$ Sponges also present chemical defenses, with higher concentrations of chemicals in their outer tissue layers, as an anti-predator mechanism. ${ }^{19}$ Therefore, seahorses may also grasp these sponges for protection.

Both S. vulgare and A. fulva may provide prey availability and shelter for both seahorse genders, but the tendency for a monogamous mating system suggests the same habitat selection. Seahorses tend to be monogamous, and monogamy seems to be reinforced by daily greetings, as reported for $\mathrm{H}$. whitei ${ }^{19} \mathrm{H}$. fuscus ${ }^{20} \mathrm{H}$. zosterae ${ }^{21}$ and $\mathrm{H}$. reidi. ${ }^{23}$ Therefore, selecting the same habitat would reduce effort and energy waste in finding a partner.

Seahorses were also found associated to marine debris, especially females. Females have a larger home range than males ${ }^{9}$ and that increases probability of using holdfasts with an appropriate shape for grasping during displacement better than protection or feeding. Other studies have also documented this for $H$. reidi,,$^{23,24,25}$ while Golani and Fine $^{26}$ and Teske et al. ${ }^{27}$ also reported marine debris and man-made holdfast use by $H$. fuscus and $H$. capensis Boulenger 1900, respectively. Hippocampus comes Cantor 1850 has been reported using pieces of wood and submerged cables, ${ }^{14}$ and $H$. reidi has been noted as grasping pieces of wood. ${ }^{6}$ However, none of the aforementioned studies have linked selection with availability.

The results reported herein indicate that $H$. reidi is frequently associated with $S$. vulgare, Dictyota sp. and A. fulva, which play an important role in the ecology of this seahorse species. No significant difference between male and female habitat selection was observed. The strong association between $H$. Reidi and S.vulgare beds suggests seahorse vulnerability to the degradation of this habitat, as also reported by Aylesworth et al. ${ }^{8}$ for mangroves. Seahorse conservation must, therefore, be geared towards the conservation of their habitats, as they depend on these environments for survival. ${ }^{28,29}$

\section{Acknowledgments}

The authors would like to thank the Santa Úrsula University for the logistic support.

\section{Funding}

None.

\section{Conflicts of interest}

The author declares that there are no conflicts of interest.

\section{References}

1. Montgomery JC, Tolimeri N, Haine OS. Active habitat selection by presettlement reef fishes. Fish and Fisheries. 2001;2(3):261-277.

2. Balshine S, Sloman KA. Parental Care in Fishes. In: Farrell A, editors Encyclopedia of Fish Physiology, From Genome to Environment, San Diego. 2011;1:670-677.

3. Lourie SA, Vincent ACJ, Hall HJ. Seahorses: an identification guide to the world's species and their conservation. London, Project Seahorse. 1999.

4. Lima SL, Dill LM. Behavioral decisions made under the risk of predation: a review and prospectus. Canad J Zool. 1990;68(4):619-640.
5. Freret-Meurer NV, Andreata JV, Alves MAS. Activity rate of the seahorse Hippocampus reidi Ginsburg, 1933 (Syngnathidae). Acta Ethol. 2012;7:1.

6. Rosa IL, Oliveira TPR, Castro AL, et al. Population characteristics, space use and habitat associations of the seahorse Hippocampus reidi (Teleostei: Syngnathidae). Neotrop Ichthyol. 2007;5:405-414.

7. Rosa IL, Dias TL, Baum JK. Threatened fishes of the world: Hippocampus reidi Ginsburg, 1933 (Syngnathidae). Environm Biol. Fish. 2002;64:378.

8. International Union for Conservation of Nature - IUCN. 2010. Red List of threatened species.

9. Aylesworth L, Xavier JH, Oliveira TPR, et al. Regional scale patterns of habitat preference for the seahorse Hippocampus reidi in the tropical estuarine environment. Biod Conser. 2015;49(4):499-512.

10. Freret-Meurer NV, Fernandez TC, Okada NB, et al. Population dynamics of the endangered seahorse Hippocampus reidi Ginsburg, 1933 in a tropical rocky reef habitat. Anim Biodiv Conserv. 2018;41:345-356.

11. Freret-Meurer NV, Vaccani AC, Okada NB, et al. A snapshot of a high density seahorse populationin a tropical rocky reef. $J$ Nat Hist. 2018;52:1571-1580.

12. Freret-Meurer NV, Andreata JV. Field studies of a Brazilian seahorse population, Hippocampus reidi Ginsburg, 1933. Brazil Archiv Biol Technol. 2008;51(4):743-751.

13. Lourie SA. Measuring seahorses. Technical report series. 2003;4, p. 15

14. Brusca RC, Brusca GJ. Invertebrados. Rio de janeiro, Guanabara Koogan. 2007.

15. Morgan SK, Vincent ACJ. The ontogeny of habitat associations in the tropical tiger tail seahorse Hippocampus comes Cantor, 1850. J Fish Biol. 2007;71(3):701-724.

16. Dooley JK. Fishes associated with the pelagic Sargassum complex, with a discussion of the Sargassum community. Contrib. Mar Scienc. 1972;16:132.

17. Bezerra LEA, Coelho PA. Crustáceos decápodos associados a esponjas no litoral do Estado do Ceará, Brasil. Ver Brasil Zool. 2006;23(3):699-702.

18. Castro ALC, Diniz AF, Martins IZ, et al. Assessing diet composition of seahorses in the wild using a non destructive method: Hippocampus reidi(Teleostei: Syngnathidae) as a study-case. Neotrop Ichthyol. 2008;6(4):637-644.

19. Freeman CJ, Gleason DF. Chemical defenses, nutritional quality, and structural components in three sponge species: Irciniafelix, I. campanaand Aplysina fulva. Mar Biol. 2010;157(5):1083-1093.

20. Vincent ACJ, Sandler LM. Faithful pair bonds in wild seahorses, Hippocampus whitei. Anim Behav. 1995;50(6):1557-1569.

21. Vincent ACJ. A role for daily greetings in maintaining seahorse pair bonds. Anim Behav. 1995;49(1):258-260.

22. Masonjones HD, Lewis SM. Courtship behavior in the dwarf seahorse, Hippocampus zosterae. Copeia.1996;634-640.

23. Oliveira TPR, Castro ALC, Rosa IML. Novel sex-related characteristics of the longsnout seahorse Hippocampus reidi Ginsburg, 1933. Neotrop. Ichthyol. 2010;8(2):373-378.

24. Dias TLP, Rosa IL. Habitat preferences of a seahorse species, Hippocampus reidi(Teleostei: Syngnathidae) in Brazil. Aqua. J Ichthyol Aquat Biol. 2003;6(4):165-176.

25. Marcus JE, Samoilys M, Meeuwing J, et al. Benthic status of nearshore fishing grounds in the central Philippines and associated seahorse densities. Mar Pollut Bullet. 2007;54(9):1483-1494.

26. Mai ACG, Rosa IML. Aspectos ecológicos do cavalo-marinho Hippocampusreidino estuário Camurupim/Cardoso, Piauí, Brasil, fornecendo subsídios para a criação de uma Área de Proteção Integral. Biota Neotrop. 2009;9(3):85-91. 
27. Golani D, Fine M. On the occurrence of Hippocampus fuscus in the eastern Mediterranean. JFish Biol. 2002;60(3):764-766.

28. Teske PR, Lockyear JF, Hecht T, et al. Does the endangered Knysna seahorse, Hippocampus capensis, have a preference for aquatic vegetation type, cover or height. Afr Zool. 2007;42(1):23-30.
29. Krebs CJ. Ecological Methodology. New York, Harper Collins Publishers. 1999. 